\title{
MONIZA ALVI AS A DIASPORA POET
}

\section{Dr. Naresh M. Solanki}

\begin{abstract}
'Diaspora' refers to the dispersion of people from their homeland. It is a scattered population whose origin lies in a separate geographic scale. Diaspora Literature can be called works were written by authors who live outside native land. Diaspora writers are often preoccupied with the elements of nostalgia as they seek to locate themselves in the new culture.At the core of the concept of Diaspora lays the image of home. Home is a powerful notion in the study of Diaspora.
\end{abstract}

Here, I have presented my study of the notion of Homeland in Diaspora and its elements. For that, I have taken poems of Moniza Alvi from her anthology "Split World: Poems (19902005)". Moniza Alvi is a Pakistani-British poet and writer. She was born in Pakistan and grew up in England. In some of her poems, she drew the image of Homeland, which has glimpses of nostalgia. The split world includes poems of five collections. Here, I have examined how Homeland reflects in Alvi's poems and how she reconstructs home through poetry. Further, my conclusion is that the identity of Homeland has held onto those people living in host land and it reflects in their works.

Keywords: Diaspora literature, Moniza Alvi, Homeland, Women's writing, Diaspora: Origin, Literature, and influence

The word Diaspora derives from the Greek word meaning "to disperse/scatter". It refers 
Towards Excellence: An Indexed, Refereed \& Peer Reviewed Journal of Higher Education / Dr. Naresh $\underline{\text { Solanki / Page 460-470 }}$

to the dispersion of people from their homeland; it is the displacement of community/culture into another geographical and cultural region. The Greek term, Diaspora was originally coined to describe the experiences of the Jewish people after the Babylonian captivity of 586 B.C. The term eventually extended to refer to other people who are dispersed from their native lands. Diaspora includes those who were enslaved, those who choose to migrate for reasons of labor and trade, and those who were exiled for political reasons. Robin Cohen in his book 'Global Diasporas: An Introduction' defines Diaspora as “communities living together in country who acknowledge that the old country- a nation often buried deep in language, religion, custom or folklore- always has some claim on their loyalty and emotion...a member's adherence to a diasporic community is demonstrated by an acceptance of an inescapable link with their pass migration history and a sense of co-ethnicity with others of similar background."

Diaspora literature can be defined as, works that are written by an author who lives outside their native land. The term identifies a work's distinctive geographic origins. Diasporic literature is influenced by the migratory experiences of the displaced communities. This literature reflects a change in social, political, and cultural realities while maintaining a connection to common cultural heritage. The characters and themes are about issues in assimilation into a new land and new culture.

There is a cultural representation of society in diasporic writing. Moreover, there is a deep connection with home. The Diaspora litterateur deals with questions of- identity, nationhood, hegemony, hybridity, alienation, bicultural pull, cultural differences, uprooting and rerooting, nostalgia, etc. These can be called experiences of Diaspora.

Diaspora writers are often preoccupied with the elements of nostalgia as they seek to locate themselves in a new culture. They write concerning the culture of their homeland and at the same time adopt and negotiate with the cultural space of the host land. They project cultural phenomena of homeland through their writings. Meena Alexander defines it as, "writing in 
Towards Excellence: An Indexed, Refereed \& Peer Reviewed Journal of Higher Education / Dr. Naresh Solanki / Page 460-470

search of homeland". Diasporic writers live on the margins of the two countries and create cultural theories. The diasporic writers turn to their homelands for various reasons. Like for rerooting, mythologies and histories, memories and nostalgia, etc.

Diaspora literature helps in understanding various cultures, breaking the barriers between different countries. It is a powerful network connecting the entire globe. It helps in the circulation of information. This literature helps to rediscover the commonality and 
Towards Excellence: An Indexed, Refereed \& Peer Reviewed Journal of Higher Education / Dr. Naresh $\underline{\text { Solanki / Page 460-470 }}$

inclusiveness of a homeland. This literature has made possible removal of all kinds of barriers and limitations- traditional, cultural, linguistic, etc. Diaspora literature has its influences on the field of education, too. It includes the study of the experience of migration, hybridity, displacement. There is no one model for such experiences, each Diaspora is different, as are the response of different members of the community. Diaspora literature has its influences on theater as many movies are adaptations of Diaspora literature; moreover, it is inspiring them to portray experiences of dispersed people and their lives. Diaspora in literature is increasing its space.

Notion of Homeland

The core concept of Diaspora lays the image of a remembered home that stands at a distance both temporally and spatially. This' place of origin' may be the focus of the sustained ideology of return; it can still figure as home in the present or be seen as belonging to entirely past. It may have been left recently or generations ago; it may not exist anymore or be the destination of regular home trips; it may be a locus of nostalgia; it may feel welcoming or strange upon return visits. Somehow it is imagined re-created, longed for, and remembered in present through diasporic imaginary.

Memories of home are no factual reproduction of a fixed past. Rather they are reconstruction set against the backdrop of the remembering subject's current positioning and conceptualizations of home. There are differences between first-generation migrants, who can relate their diasporic experiences to their memories of a time before migration, and for later generations for whom the ' new land' has never been new and whose memories of 'homeland' are more fragmented. This layeredness of contemporary perceptions of home resonates in many complex ways the 'original home' is remembered. 
Towards Excellence: An Indexed, Refereed \& Peer Reviewed Journal of Higher Education / Dr. Naresh $\underline{\text { Solanki / Page 460-470 }}$

Memories, both personal and collective, from the frame of reference we all use meaningfully to interpret our past and present experiences. This means that migrants' perceptions and dreams of home and belonging are fuelled by memories of prior homes, by notions of where 'we' came from. Memory, however, cannot be seen as direct if partial, knowledge of experiences. The act of remembering is an always continuous process of recalling, interpreting, and reconstruction of the past.

In the diasporic study, the notion of home is referred to and employed in contradictory ways. This concerns relationship of migrants to 'original homeland' and questions of feeling at home. The first focuses on myths of migration and dreams of return; while the second trace the desires and possibilities of making oneself at home mainly in current space or residence. This reproduces a dichotomy between 'homeland as the object of longing and host land as the object of efforts to belong'. Thus the notion of home is not bound to physical places but also the symbolic space of belonging.

There is a centrality of remembered home in the concept of Diaspora. It refers to multiple places and spaces in past. Home can be remembered, loved, and longed for. Notions of home are lucid and bound to change as one move in space and time. Rather than referring to one single home, in diasporic settings feelings of belonging can be directed towards multiple physical places and remembered, imagined, or symbolic space. Home can be conceptualized as a place, space, or feeling. Home can be described or related to house, family, haven, self, gender, journeying. Home can be connected to memory and identity, to the origin as well as hybridity.

Home is a highly relevant term for diasporic subjects. For them, it can be lived in reality, but it can also suggest self-evidence. In imaginary, it is strong undertones of familiarity, continuity, safety, unproblematic belonging, exclusivity, and warm memories which make a 
Towards Excellence: An Indexed, Refereed \& Peer Reviewed Journal of Higher Education / Dr. Naresh $\underline{\text { Solanki / Page 460-470 }}$

home so compelling and inform migrants' homing desires. There is a creative tension between the notion of 'home where the heart is' and the layeredness of home as an analytical concept which makes it a powerful idea in the study of Diaspora.

Moniza Alvi

Moniza Alvi is a Pakistani-British poet and writer. She was born in Lahore, Pakistan to a Pakistani father and British mother. Her father moved to Hatfield, Hertfordshire, in England when Alvi was a few months old. She grew up in England and studied in the universities of York and London. She did not revisit Pakistan until after the publication of one of her first books of poems - The Country at My Shoulder. She worked for several years as a high-school teacher but is now a freelance writer and tutor. She is a fellow of the English Association and trustee of the Poetry Society and the magazine Poetry London. She has written a collection of poems Peacock Luggage, a book of poems by Moniza Alvi and Peter Daniels, was published as a result of the two poets jointly winning the Poetry Business Prize in 1991. Since then, Moniza Alvi has written eight poetry collections.

The Country at My Shoulder (1993), which was shortlisted for the T. S. Eliot Prize and the Whitbread Poetry Award.Europa (2008), a Poetry Book Society Choice and shortlisted for the TS Eliot Prize. Also published in 2008 Split World includes poems from her first five collections. Homesick for the Earth (2011) selected poems by the French poet Jules Supervielle with versions by Moniza Alvi. At the Time of Partition (2013) a Poetry Book Society Choice, shortlisted for the 2013 TS Eliot Prize and won the East Anglican Writers Prize for poetry. Alvi's latest collection is Blackbird, Bye Bye and will be published on the 21st of June 2018.s.

In her early work, she drew on real and imagined homelands in vivid poems. Her less biographical later books are concerned only with divisions of East and West but also with the 
Towards Excellence: An Indexed, Refereed \& Peer Reviewed Journal of Higher Education / Dr. Naresh Solanki / Page 460-470

interplay between inner and outer worlds, imagination and reality, physical and spiritual. Alvi's poetry is imbued with a spirit of duality, partition, fractured identity, and transformation.

Elements of Homeland in Alvi's poems

Here, I have examined how Homeland reflects in Moniza Alvi's poems and how she reconstructs home through poetry. For that, I have taken some poems from her anthology 'Split World: Poems (1990-2005)'.

The poem 'Indian Cooking', as the title suggests is about experiencing the notion of home through cooking or food. Here, India is in the context of both the countries India and Pakistan, as before partition it was one nation. Here we can see spices are symbols of culture;

"The bottom of the pan was a palette-

paprika, cayenne, dhania

haldi, heaped like powder-paints"

The pan as a palette suggests nation and spices as a variety of cultures, powder-paint can be symbolized as a festival of Holi.

"I tasted the landscape, customs

Of my father's country-“

Here, it's about how the author comes to know about her father's homeland through cooking. Cooking is a part of tradition and culture, and she uses it as a symbol to experience the homeland of her father. It is a presentation of the second generation's experience of home.

The second poem is 'Presents from my aunts in Pakistan'. Alvi talks about presents her aunts sent from Pakistan salwar kameez, slippers, bangles, and sari. She talks about how her aunts wanted cardigans from Marks and Spencers. 
Towards Excellence: An Indexed, Refereed \& Peer Reviewed Journal of Higher Education / Dr. Naresh $\underline{\text { Solanki / Page 460-470 }}$

Here, these presents are sent from Alvi's homeland, so they are precious for her the way she described her presents shows reflections of her home how clothes looked like their colors and radiance. She says fashions changed in Pakistan, the pattern of salwar bottoms changed.

\section{"I longed for denim and corduroy.}

\section{My costume clung to me}

And I was aflame,

\section{I couldn't rise out of its fire,"}

Here, the author yearns for solace in holland but homeland has held onto her that severally she falls into flashbacks and memories of the homeland.

"My presents were radiant in my wardrobe."

Presents signify memory of the homeland, so it suggests a memory of Home is radiance or its most remembered and most important in her life or amongst her experiences. The presents from Pakistan were a precious part of her wardrobe. She also describes the journey from Pakistan to England. And fractured land as Pakistan's partition from India and her memory of her aunts in Pakistan. The poem signifies the culture of the homeland, longing for home in the host-land, memories of home. Alvi has recreated the homeland in her poem.

The next poem I've taken is 'Lukbir'; it's about Alvi's aunt who lived traditionally. She talks about how she used to wear traditional clothes; though she was well literate she had no wish for a job. She talks about how the author used to imagine her aunt in a western hairstyle and stepping outside. She tells how her aunt died at a young age and her uncle tried everything to get over from memories. Here, the author's aunt represents homeland and the uncle represents host land. Aunt is not influenced by host land and she keeps reminding of Homeland through her lifestyle. 
Towards Excellence: An Indexed, Refereed \& Peer Reviewed Journal of Higher Education / Dr. Naresh Solanki / Page 460-470

The next poem is 'The Sari'. Her sari is a metaphor for distance between geographical locations. Sari is the identity of the country and it shows the distance between lands. She uses words 'hot' and 'brown' for weather and brown signifies people from eastern countries. Sari is country and sari is unraveling distance between lands as we can see below;

"All the people unravelled a sari.

It stretched from Lahore to Hyderabad,

Wavered across the Arabian Sea,

Shot through with stars,

fluttering with sparrows and quails.

They threaded it with roads,

Undulations of land."

Alvi ends her poem by saying 'Your body is your country'. The poem signifies the idea of the distance between homeland and host land and the author gives the idea of the geographical location of her country.

She shows from poem distance from her homeland.

The next poem is 'Hindi Urdu Bol Chal'. Alvi connects language to nation and culture. Hindi to India and Urdu to Pakistan. She says she tries to touch these languages through her tongue, it means she tries to connect with these lands through the medium of languages. She is traveling through countries with languages. Here, the notion of home is symbolic. She presents her homeland through language and sound system, as

"The village conferences, the crackling

Of bonfires and the rap of gunfire." 
Towards Excellence: An Indexed, Refereed \& Peer Reviewed Journal of Higher Education / Dr. Naresh $\underline{\text { Solanki / Page 460-470 }}$

'Lahore canal' is a poem where Alvi presents the scene of noon in Lahore and imagines herself there. She presents a picture of the Lahore canal

"As I glimpse the agile boys

Plunging into the Lahore Canal

Escaping the torment of the sun,"

The poem has a central idea of remembered home. She imagines herself being there in the afternoon. Alvi through memory presents the idea of homeland.

\section{Conclusion}

My conclusion here is that identity of the homeland has held onto people who are dispersed from the homeland and living in host land, thus that hold of homeland reflects in their work as Moniza Alvi's poetry reflects her Homeland. A study of Moniza Alvi's work presents the idea that her works have the influence of homeland memories and it reflects homeland. She recreates memories and atmosphere of homely feeling in her poems. These homely feeling of comfort, acceptance, and identity gets lost in host land. A cultural background, languages, traditions of host land becomes hard to accept for dispersed people they end up having issues of acceptance and identity. The search for a home in host land leads to memories and experiences of the homeland. Thus, Homeland as the origin of identity claims a stronghold on dispersed people. This hold and a strong influence of the homeland's memories and experience intrigue in acceptance of host land. Thus, from the study of Alvi's work, it turns out that homeland claims hold onto people who are living in host land and so that hold of homeland reflects in their work. 
Towards Excellence: An Indexed, Refereed \& Peer Reviewed Journal of Higher Education / Dr. Naresh $\underline{\text { Solanki / Page 460-470 }}$

\title{
Bibliography
}

Knott. and McLoughlin,S. (eds)(2010),Diasporas: concepts, intersections, identities ,London ,7Cynthia streets, Zed books Ltd.

Alvi, Moniza (2008), Split World: poems (1990-2005), Tarset, Highgreen, Bloodaxe Books Ltd.

Paranjape,Makrand(ed)(2001), “Introduction”, Diaspora theories: Histories, texts, New Delhi, Indialog

https://link.springer.com/chapter/10.1007/978-94-010-2456-3_1

https://www.moniza.co.uk

\author{
Dr. Naresh M. Solanki \\ Head, Department of English, \\ Dr. Subhash Mahila Arts, Commerce \& Home Science College, Junagadh \\ Email: nareshsolanki456@gmail.com
}

